\title{
Accumbal 14-3-3 $\zeta$ Protein Downregulation Is Associated with Cocaine-Conditioned Memory
}

\author{
Gour-Shenq Kao ${ }^{a}$ Jia-Ying Chuang ${ }^{a}$ Chian-Fang G. Cherng ${ }^{c}$ Lung Yu ${ }^{a}$ b \\ Institutes of a Basic Medical Sciences and ${ }^{b}$ Behavioral Medicine, National Cheng Kung University College of \\ Medicine, and 'Department of Health Psychology, Chang Jung Christian University, Tainan, Taiwan, ROC
}

\section{Key Words \\ Conditioned place preference $\cdot$ Nucleus accumbens • Cocaine memory $\cdot$ Conditioned cues $\cdot$ Reinstatement}

\begin{abstract}
Cocaine-conditioned memory has been known to cause cocaine craving and relapse, while its underlying mechanisms remain unclear. We explored accumbal protein candidates responsible for a cocaine-conditioned memory, cocaine-induced conditioned place preference (CPP). Two-dimensional gel electrophoresis in conjunction with liquid chromatography mass spectrometry analysis was utilized to identify accumbal protein candidates involved in the retrieval of cocaine-induced CPP. Among the identified candidate proteins, a downregulated $14-3-3 \zeta$ protein was chosen and confirmed by Western immunoblotting. A polymer-mediated plasmid DNA delivery system was then used to overexpress 14-3-3 protein in mouse nucleus accumbens before the CPP retrieval tests. Overexpression of accumbal 14-3-3 $\zeta$ protein was found to diminish conditioned cue/context-mediated cocaine-induced CPP. In contrast, another isoform of 14-3-3 protein, 14-3-3 $\varepsilon$ protein, did not affect conditioned cue/context-mediated cocaine-induced CPP. Overexpres-

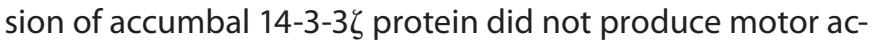

tivity-impairing effect or alter local dopamine metabolism. Moreover, overexpression of accumbal $14-3-3 \zeta$ protein did not affect food-induced CPP. These results, taken together, indicated that overexpressed accumbal $14-3-3 \zeta$ protein specifically decreased conditioned cue/context-mediated cocaine memory. Further understanding of the function of accumbal $14-3-3 \zeta$ protein may shed light on the treatment of cocaine craving and relapse.

Copyright $\odot 2011$ S. Karger AG, Base

\section{Introduction}

One of the most challenging problems for drug-dependence treatment is addicts' long-lasting vulnerability to drug craving during abstinence [1]. Aside from the drug itself, context and discrete cues associated with drug use are found to induce drug craving and conditioned emotional responses in abstinent addicts $[2,3]$. Treatment of cocaine addiction frequently fails because of ineffective prevention of the conditioned cue/context-induced craving [4]. Likewise, accrued evidence demonstrates that the presence of drug-conditioned cues and context reinstates the drug taking/seeking behavior during withdrawal in many animal models [5-12]. There- 
fore, it is of importance to understand the underlying mechanisms of drug-conditioned cue/context memory. Cocaine-induced conditioned place preference (CPP) serves as an excellent model for studying cocaine-conditioned cue/context memory in this regard. In this model, cocaine-conditioned cue/context induces animals' preference to the cocaine-associated place for a period of time even when cocaine is not provided any longer after conditioning. Previously, we demonstrated that newly synthesized proteins are involved in the consolidation, expression and reconsolidation of this cocaine-conditioned memory [13-15]. However, the roles of specific proteins in mediating the retrieval of this cocaine memory remain unexplored. In the present study, a proteomic approach, two-dimensional gel electrophoresis (2-DE) in conjunction with liquid chromatography mass spectrometry analysis was employed to identify the protein candidates associated with the retrieval of this cocaine memory. A polymer-mediated plasmid DNA delivery system was then used to express specific proteins to assess their roles in mediating the retrieval of such a cocaine memory.

It has been well established that cocaine may activate the mesolimbic dopamine (DA) system that normally mediates the reinforcing value of naturally occurring unconditioned stimuli. The nucleus accumbens (NAc) is one primary projection target of the mesolimbic DA system. Repeated cocaine injections are found to induce synaptic plasticity in the NAc $[16,17]$. Cocaine-induced CPP training activates extracellular receptor kinase in the NAc, while intra-accumbal infusions of an extracellular receptor kinase inhibitor prevents the expression of cocaineinduced CPP [18]. Moreover, modulation of chromatin modification in the NAc facilitates cocaine-induced CPP extinction and prevents the reinstatement of this memory [19]. Most importantly, NAc is implicated in conditioned cue-elicited drug seeking behavior in many animal studies [20-23]. Taken together, these results all support the notion that NAc could be one of the memory storage sites of cocaine-induced CPP. We accordingly hypothesized that specific protein expression in the NAc may be involved in this cocaine-conditioned memory. Therefore, we decided to study the roles of accumbal protein candidates in mediating the retrieval of cocaine-induced CPP.

\section{Materials and Methods}

\section{Animals}

Male C57BL/6 mice were used at 8-9 weeks of age. Mice were housed in a facility located at National Cheng Kung University Laboratory Animal Center (Tainan, Taiwan). Mice had free access to food (Purina Mouse Chow, Richmond, Ind., USA) and tap water throughout the experiments. The colony room was temperature- and humidity-controlled and maintained on a 12-hour light/dark cycle (lights on at 07:00). This study was performed in accordance with the National Institutes of Health Guide for the Care and Use of Laboratory Animals. All experimental procedures were approved by the local Animal Care Committee at National Cheng Kung University College of Medicine.

\section{Cocaine-Induced CPP Training, Test and Cocaine-Priming}

Test

Pretest, cocaine-induced CPP training, test and cocaine priming test were all conducted in commercial chambers designed for mice (MedAssociates Inc., Georgia, Vt., USA) as described in our previous reports $[13,14]$. Mice of the paired and unpaired groups were placed in the center of any randomly chosen chamber and their time spent in each compartment of the chamber was measured for unconditioned preference in a 15-min pretest on day 1 . Mice spending $<40 \%$ of the time in any one compartment or center were included in the study. For cocaine-induced CPP training (days 2-9), mice receiving an intraperitoneal injection of cocaine hydrochloride $(5 \mathrm{mg} / \mathrm{kg})$ or an equivalent volume of saline injection were immediately confined in one randomly assigned compartment of their pretest chambers for $30 \mathrm{~min}$. Eight hours apart, these mice received a saline or cocaine hydrochloride $(5 \mathrm{mg} / \mathrm{kg})$ injection and were immediately confined in the other compartment for $30 \mathrm{~min}$ in the corresponding chambers. These procedures were repeated for another 7 consecutive days. On days 10, 17 and 25 around noon, mice were placed in the center of their corresponding chambers with guillotine doors open and started a 15 -min preference test (i.e. test 1,2 and 3 ) in a cocaine-free status. On day 24 around noon, mice receiving an injection of cocaine solution $(2.5 \mathrm{mg} / \mathrm{kg})$ were placed in the center of their respective chambers with guillotine doors open and started a 15min cocaine-priming test. Durations (in seconds) for mice exploring each of the 3 compartments were recorded in tests 1, 2 and 3 , and the cocaine-priming test. Cocaine-induced CPP magnitude was represented by subtracting the time spent in the saline-paired compartment from the time spent in the cocainepaired compartment for each mouse.

\section{2-DE and Candidate Protein Determination}

In an attempt to exclude any obvious confounding caused by cocaine treatment per se, 2 groups of mice were used for candidate protein specification and identification experiment. One group (paired group) of mice received cocaine-place conditionings in a paired manner. The other group (unpaired group) of mice received cocaine injections and place conditionings in an unpaired way. That is, mice of the paired group receiving an intraperitoneal injection of cocaine hydrochloride $(5 \mathrm{mg} / \mathrm{kg})$ and an equivalent volume of saline injection were immediately confined in one randomly assigned compartment of their corresponding chambers for $30 \mathrm{~min}$. In contrast, mice of the unpaired group received cocaine and vehicle injections in their home cages and were kept in their respective chambers for $30 \mathrm{~min} 2 \mathrm{~h}$ after injections. These procedures were repeated for another 7 consecutive days for paired and unpaired groups. Both paired and unpaired groups of mice were sacrificed $1 \mathrm{~h}$ after the cocaine-induced CPP test by rapid decapitation and their accumbal tissues were dissected. Since the paired group, not the unpaired group, was expected to 
exhibit cocaine-induced CPP, differential expression of accumbal proteins between the paired and unpaired groups could be attributed to the retrieval of cocaine-induced CPP. Therefore, a 2-DE in conjunction with liquid chromatography mass spectrometery was employed to specify and identify protein candidates in accumbal samples from mice of the paired and unpaired groups. 2-DE was performed using isoelectric focusing as the first dimension (IPGphor, Amersham Biosciences, Uppsala, Sweden) using an immobilized $\mathrm{pH}$ gradient strip (IPG strip, $18 \mathrm{~cm}$ in length, linear $\mathrm{pH} 4-7$ ) followed by the second dimensional sodium dodecyl sulfate-polyacrylamide gel electrophoresis (Protean II xi cell, BioRad, Calif., USA) [24]. The in-gel digestion, mass spectrometry analysis, and database search were performed as described in our previous report [24].

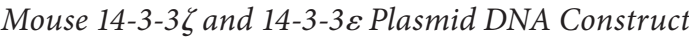

We utilized reverse transcription-polymerase chain reaction (RT-PCR) to construct the complete open reading frames (ORFs) of $14-3-3 \zeta$ and $14-3-3 \varepsilon$ from mouse brain full-length cDNA library. In brief, the mouse 14-3-3s ORFs were amplified from male C57BL/6 mouse whole brain full-length cDNA library by RT-PCR using Pfu Turbo HotStart polymerase (Stratagene, La Jolla, Calif., USA). The 754 base-pair of $14-3-3 \zeta$ product was then cloned into pcDNA3.1/myc-His $\mathrm{B}^{+}$(Invitrogen, La Jolla, Calif., USA) and the 787 base-pair of 14-3-3 $\varepsilon$ product was cloned into pcDNA3.1/myc-

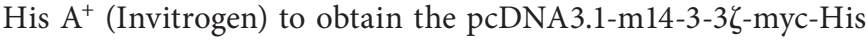
and pcDNA3.1-m14-3-3 $\varepsilon$-myc-His constructs. These constructs were used for expression of the mouse $14-3-3 \zeta$ and $14-3-3 \varepsilon$ proteins, respectively, in infected accumbal neurons.

\section{Preparation of the PEI-Mediated Plasmid DNA Delivery \\ System}

Since nonviral vectors were proven to be low-toxic and longlasting for in vivo gene transfer in adult mouse brain [25], a cationic polymer, polyethylenimine (PEI), was used as a nonviral plasmid DNA delivery vehicle. PEI, known to condense plasmid DNA into positively charged nanoparticles in order to interact with ${ }^{\mathrm{TM}}$ anionic proteoglycans at the cell membrane, enabled plasmid DNA delivery into cytoplasm via endocytosis $[26,27]$. In addition, PEI may act as a proton sponge to buffer the endosomal $\mathrm{pH}$, thus protecting plasmid DNA from degradation [26, 27]. Since effective cell entry depends on the amount of cationic particles, a net cationic balance of mixing cationic PEI with anionic plasmid DNA was favored. The N/P ratio, the number of nitrogen residues of in vivo-jetPEITM (Polyplus Transfection, Illkirch, France) per DNA phosphate, is a measure of the ionic balance of the PEI and plasmid DNA mixture. Therefore, the N/P ratio was determined to be $6(1 \mu \mathrm{g}$ DNA was mixed with $0.12 \mu \mathrm{l}$ in vivojetPEI) according to the manufacturer's instructions. For preparation of our PEI-mediated plasmid DNA delivery system, PEI (in vivo-jetPEI; Polyplus Transfection) was mixed with a plasmid en-

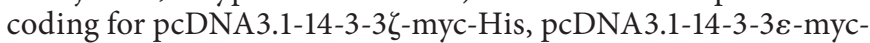
His (both were driven by a cytomegalovirus promoter) or a plasmid encoding for pcDNA3.1-myc-His (i.e. vector only).

\section{Stereotaxic Surgery and Cannula Implantation}

In an attempt to avoid anesthesia-associated interference with mouse performance, mice underwent stereotaxic surgery and 26-gauge guide cannula implantation (coordinates: anteroposterior $+1.34 \mathrm{~mm}$; lateral $-0.70 \mathrm{~mm}$; dorsoventral $-4.50 \mathrm{~mm}$; the dor- soventral coordinate was measured from the skull) was done 1 week before starting the pretest. Clearance through the guide cannula was maintained with dummy cannulas. The infusion cannula, a 33-gauge dental needle, was inserted into the guide cannula and was lowered $2.0 \mathrm{~mm}$ below the guide cannula toward the center of the NAc. The infusion cannulas were mostly in or bordered on the NAc. Data from mice with any side of the infusion cannula position outside this range in histological checks were excluded for further analyses.

\section{Behavioral Procedures}

Although downregulation of accumbal 14-3-3 $\zeta$ proteins was found to be associated with the expression of cocaine-induced CPP in the 2-DE experiment, whether accumbal 14-3-3 $\zeta$ downregulation was involved in the acquisition and/or retrieval of cocaine-induced CPP remains unknown. Therefore, two behavioral procedures (procedures 1 and 2) were used to study the effect of accumbal 14-3-3 $\zeta$ overexpression on cocaine-induced CPP. In both procedures, mice underwent three cocaine-free tests (tests 1,2 and 3) following cocaine-induced CPP training. Intra-accumbal infusion of $14-3-3 \zeta / 14-3-3 \varepsilon$ plasmid DNA or vector was done 2 days before test 1 in procedure 1 in an attempt to determine the effect of accumbal 14-3-3 $\zeta$ overexpression on the acquisition and retrieval of cocaine-induced CPP. Intra-accumbal infusion of $14-3-3 \zeta / 14-3-3 \varepsilon$ plasmid DNA or vector was done 2 days before test 2 in procedure 2 to specifically examine the effect of accumbal $14-3-3 \zeta$ overexpression on the retrieval of cocaine-induced CPP.

\section{Locomotor Activity}

In order to rule out the possibility that overexpression of 14-3$3 \zeta$ protein into the NAc could impair mouse motor ability, mouse locomotor activity (vertical rearing and ambulatory activity in combination) was monitored in a custom-made transparent Plexiglas chamber $(41 \times 41 \times 30 \mathrm{~cm})$ inside the Optovarimax (Columbus Instrument, Columbus, Ohio, USA). Three groups of mice were used. One group of mice received no intra-accumbal infusion and the remaining 2 groups received PEI/14-3-3 $\zeta$ plasmid DNA and PEI/vector infusion, respectively. Mice were individually placed in the center of the chamber and allowed free navigation over a 30-min period (pretest). Forty-eight hours after intra-accumbal infusion of 14-3-3 $\zeta$ plasmid DNA or plasmid vector, mouse locomotor activity was measured again (posttest). The vertical infrared beam break was used as an index for the vertical rearing numbers and the horizontal distance traveled was recorded as the ambulatory activity.

\section{DA and 3,4-Dihydroxyphenylacetic Acid Determination}

The DA content level in the NAc was used to test the hypothesis that 14-3-3 $\zeta$ overexpression may alter local DA synthesis. Forty-eight hours after the 14-3-3 $\zeta$ plasmid DNA infusion, mice were killed by rapid decapitation. The brain was then removed and placed on the dorsal surface on a glass dish sitting on crushed ice. The first coronal section was taken at the center of the olfactory tubercle. The second coronal section was made at the anterior border of the hypothalamus. An NAc sample was punched out (a circle around the anterior commissure) with a 1-ml pipetman tip cutting to an internal diameter of $1.2 \mathrm{~mm}$ from the slice between these two sections. Tissue samples were wrapped in tin foil and stored immediately in liquid nitrogen until assayed by HPLC 
Fig. 1. Cocaine-induced CPP was established by a paired training schedule. These paired and unpaired mice were further used for the proteomic study. Paired mice received cocaine-induced CPP training (pairing cocaine/saline injection and compartment exploration), while unpaired mice received the same training procedure in an unpaired way (compartment exploration $2 \mathrm{~h}$ after cocaine/saline injections). Paired but not unpaired mice exhibit reliable cocaine-induced CPP in test $1 .{ }^{* * *} \mathrm{p}<0.001$.
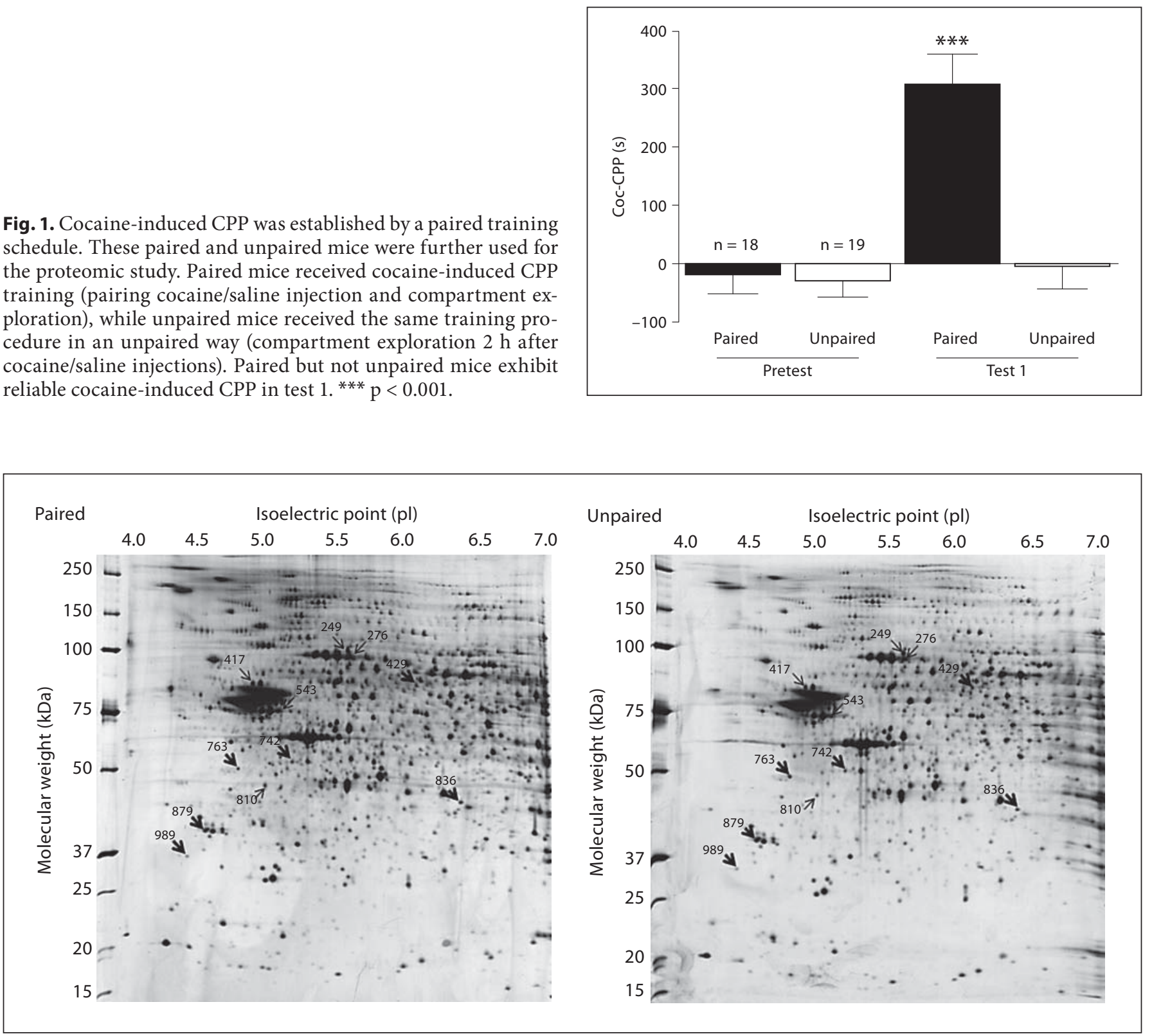

Fig. 2. A representative silver-stained 2-DE gel displays the protein spots obtained from the paired and unpaired mouse accumbal tissue samples $1 \mathrm{~h}$ after the test. Arrowheads point out the upregulated protein spots, while bold arrowheads point out the downregulated protein spots in the paired mouse accumbal tissue sample. Arabic number 879 represented the identified 14-3-3 protein spot.

with an LC-4C amperometric detector (BAS, West Lafayette, Ind., USA) to measure DA and its main metabolite, 3,4-dihydroxyphenylacetic acid (DOPAC) [27]. Tissue was homogenized and centrifuged at $14,000 \mathrm{~g}$ for $20 \mathrm{~min}$ at $4^{\circ} \mathrm{C}$. The supernatant was decanted, filtered and delivered through a high-pressure valve fitted with a $20-\mu$ l loop onto a Phase-II ODS column $(3 \mu l, 100 \times$ $3.2 \mathrm{~mm}$ ), and oxidized with a $+0.72-\mathrm{V}$ potential between the glassy carbon electrode and the $\mathrm{Ag} / \mathrm{AgCl}$ reference electrode. The mobile phase consisted of $0.1 \mathrm{M}$ sodium phosphate dibasic, $0.1 \mathrm{M}$ citric acid, $5 \mathrm{mg}$ EDTA, and 7\% methanol delivered at a 0.6-ml/ min flow rate.

\section{Food-Induced CPP Training and Test}

We decided to test whether intra-accumbal 14-3-3 $\zeta$ overexpression affected natural reward- (food) induced CPP. Pretest, food-induced CPP training and test were all conducted in com- 
mercial chambers as aforementioned. Mouse unconditioned preference for the respective chamber was determined using a similar procedure and criterion as described in the cocaine-induced CPP pretest. Throughout the experiment, mice had access to water ad libitum. However, these mice were under food deprivation and their body weights were monitored as previously reported [28]. Bilateral cannula implantation was done a week before the beginning of the pretest. Three groups of mice ( $n=5$ for each group) were used. They all received 5-day food-induced CPP trainings. Each morning, mice were confined in the non-preferred compartment where 4 sucrose pellets [28] were provided in a tray for 15 min. Eight hours apart, mice were placed in the preferred compartment where an empty tray was available for $15 \mathrm{~min}$. These procedures were repeated for another 4 consecutive days. In a 15min preference test (test 1 ), mice were placed in the center of the chambers with guillotine doors open. No sucrose pellet was provided in the preference test. Food-induced CPP was represented by subtracting the time spent in food pellet-associated compartment from the time spent in no food pellet-associated compartment. Four hours following the preference test, 2 groups of mice

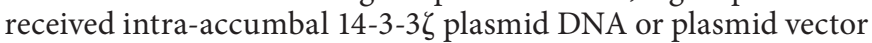
infusion, while the remaining group did not receive any infusion. Two days after infusion, 3 groups of mice underwent another 15min preference test (test 2).

\section{Statistical Analysis}

All results were indicated as the mean \pm standard error of mean. Paired t tests were used to examine the establishment of cocaine-induced CPP and food-induced CPP. One-way (plasmid DNA vs. vector treatment) repeated measure ANOVAs (across various tests) were employed to test group differences in cocaineinduced CPP and food-induced CPP magnitude. ANOVAs were used to analyze group differences in locomotor activity, DA, DOPAC levels [29], and Western immunoblotting results. The levels of statistical significance were set at $\mathrm{p}<0.05$.

\section{Results}

\section{Cocaine-Induced CPP Was Reliably Established in the} Paired Group

In the cocaine-induced CPP test, paired t tests revealed that cocaine-induced CPP was reliably established in the paired group $\left(\mathrm{t}_{34}=5.203, \mathrm{p}<0.0001, \mathrm{n}=18\right)$, but not in the unpaired group $\left(\mathrm{t}_{36}=0.5101, \mathrm{p}=0.6131, \mathrm{n}=19\right.$; fig. 1). Therefore, differential expressions of accumbal proteins between paired and unpaired groups could be very likely attributed to the retrieval of such a cocaine memory.

\section{Downregulated 14-3-3 $\zeta$ Protein in the NAc Was \\ Identified and Confirmed in the Paired Group}

One hour after the CPP test, mice were killed by rapid decapitation and their accumbal tissues were obtained. Six pairs of computer-generated images were

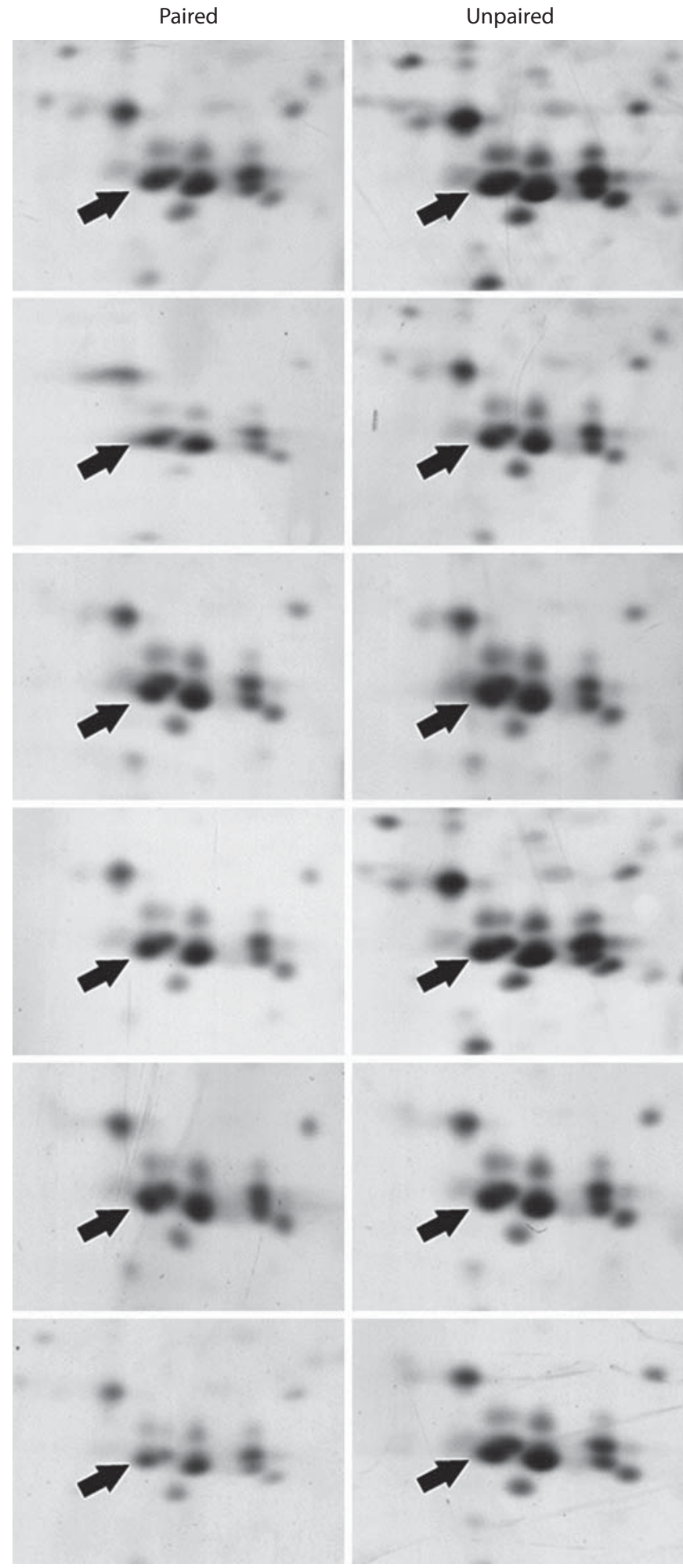

Fig. 3. Magnified images of the identified 14-3-3 gel spots in 6 matched (paired vs. unpaired) pairs of accumbal tissue samples were listed. 14-3-3 spot intensity in the paired group appears to be lower than that in the unpaired group. Arrows point out the 143-3 protein spots in both paired and unpaired groups. 
Fig. 4. Western immunoblotting results confirmed downregulated $14-3-3 \zeta$ protein in mouse nucleus accumbens of the paired group. A Paired but not unpaired mice exhibited reliable cocaine-induced CPP in test 1. B Western immunoblotting results demonstrate downregulated accumbal 143-3 $\zeta$ protein following the retrieval of cocaine-induced CPP. In contrast, $14-3-3 \varepsilon$ protein expression was not altered in the paired mouse nucleus accumbens following the retrieval of cocaine-induced CPP. ${ }^{*} \mathrm{p}<0.01$.
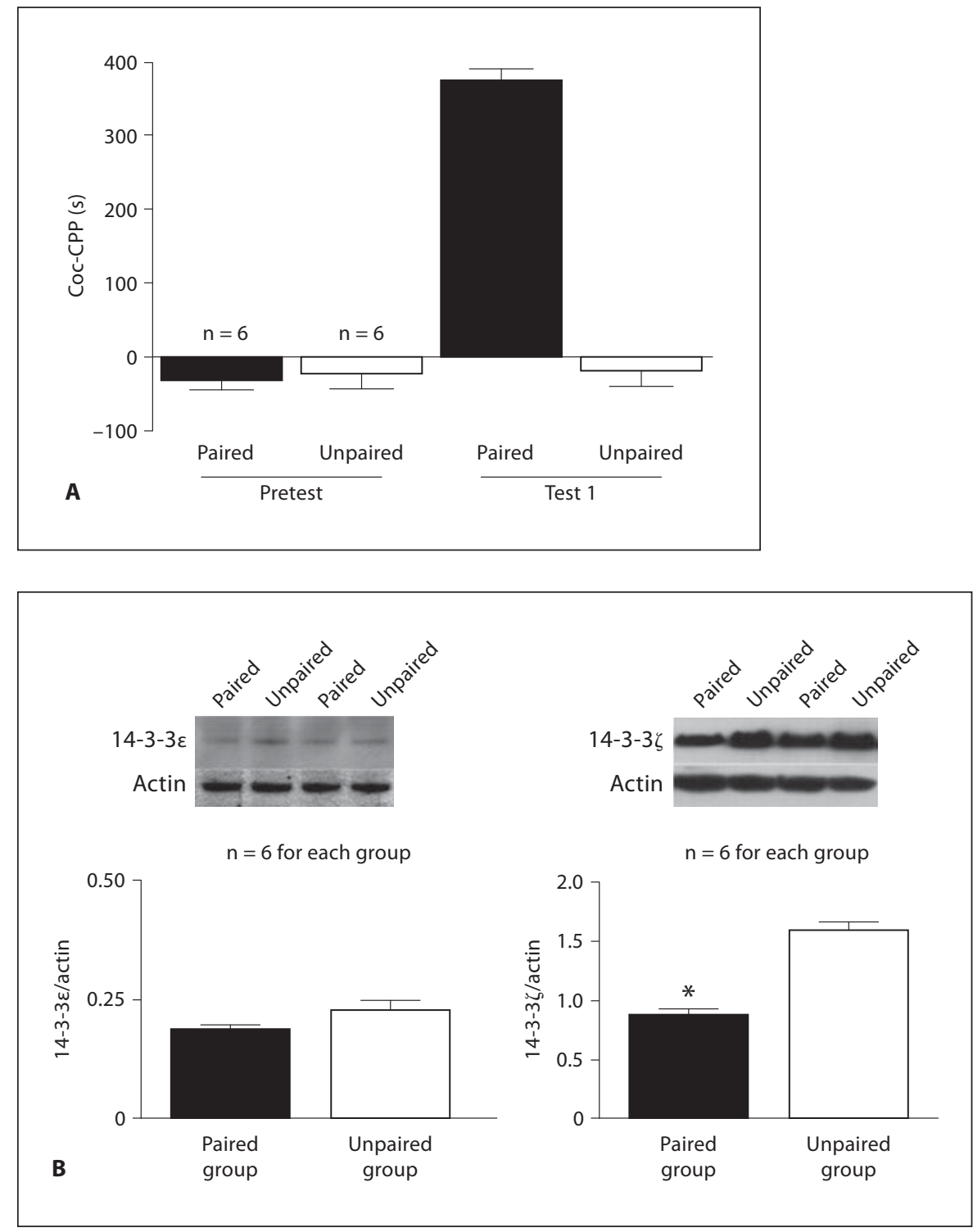

created for statistical analysis and each pair consisted of one image from the paired group and the other image from the unpaired group. In excess of 500 protein spots were detected on all of the silver-stained 2-DE gel images (fig. 2). Comparing these protein spots against the unpaired groups, five spots (dihydropyrimidinaselike 2, guanosine diphosphate dissociation inhibitor 1, ATP5b protein, thioredoxin-related protein, and an unnamed protein) were increased and six spots (14-3-3 $\zeta$, $\mathrm{t}$-complex protein 1 , guanine nucleotide binding protein $\alpha$ o, vacuolar adenosine triphosphatase subunit $D$, phosphatidylinositol transfer protein $\alpha$, and putative membrane-associated progesterone receptor component) were decreased in intensity in the paired group (fig. 2). Among these proteins, only 14-3-3 protein (including two abundant isoforms, $\varepsilon$ and $\zeta$ ) was chosen for quantification primarily due to its highest sequence coverage score. Six pairs of amplified images for the identified 143-3 protein spots in the paired and unpaired groups are listed in figure 3. Another batch (paired and unpaired groups) of mice were used to confirm this 2-DE result. Not surprisingly, our training procedure established cocaine-induced CPP in the paired group but not in the unpaired group (fig. 4A). Western immunoblotting analyses indicated that the relative level (to actin) of 143-3 $\zeta$ protein was indeed decreased following the retriev- 


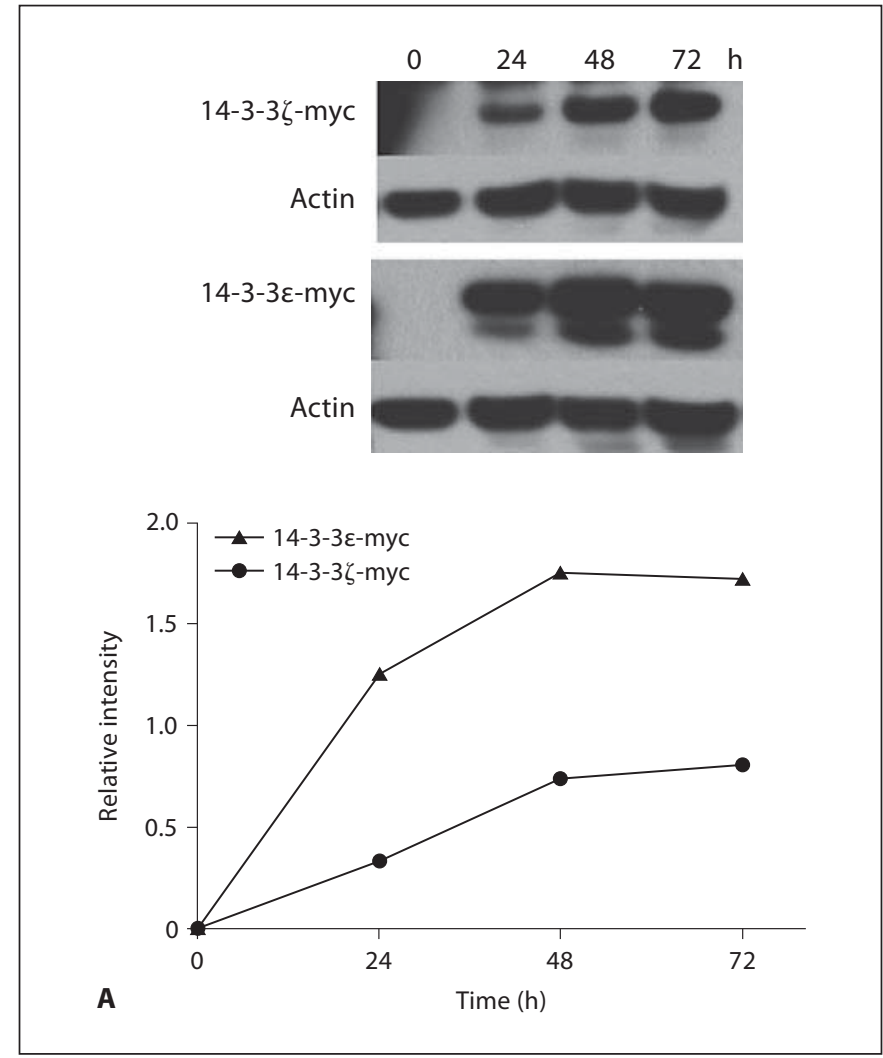

Fig. 5. Mouse $14-3-3 \zeta$ and $14-3-3 \varepsilon$ proteins were expressed in HEK293 cell line and mouse nucleus accumbens following plasmid DNA delivery. A The HEK293 cells were transfected with PEI and pcDNA3.1-14-3-3 -myc-His plasmid DNA and pcDNA3.114-3-3e-myc-His plasmid DNA mixture at $80 \%$ confluence in $6-\mathrm{cm}^{2}$ cell culture dishes $\left(5.0 \times 10^{5} / 60 \mathrm{~mm}^{2}\right)$ using Lipofectamine LTX reagent. Expressed myc proteins across time were quantified. Myc protein expression peaked at $48 \mathrm{~h}$ after PEI-mediated trans-

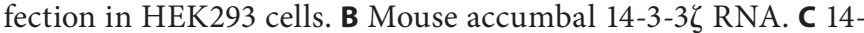

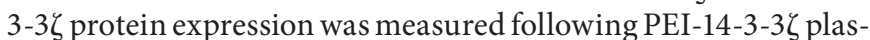
mid DNA mixture infusion into mouse nucleus accumbens. 14-3-3 $\zeta$ protein expression was found to peak at $48 \mathrm{~h}$ after PEI-mediated transfection in accumbal tissue extracts.

al of cocaine-induced CPP in the paired group $\left(\mathrm{t}_{10}=\right.$ $3.379, \mathrm{p}=0.007, \mathrm{n}=6$ ), while the relative level of $14-3-3 \varepsilon$ protein was not altered after the retrieval of cocaine memory in the paired group $\left(\mathrm{t}_{10}=0.6107, \mathrm{p}=0.555, \mathrm{n}=\right.$ 6; fig. 4B).

Accumbal 14-3-3 $\zeta$ Protein Downregulation Cocaine-Conditioned Memory

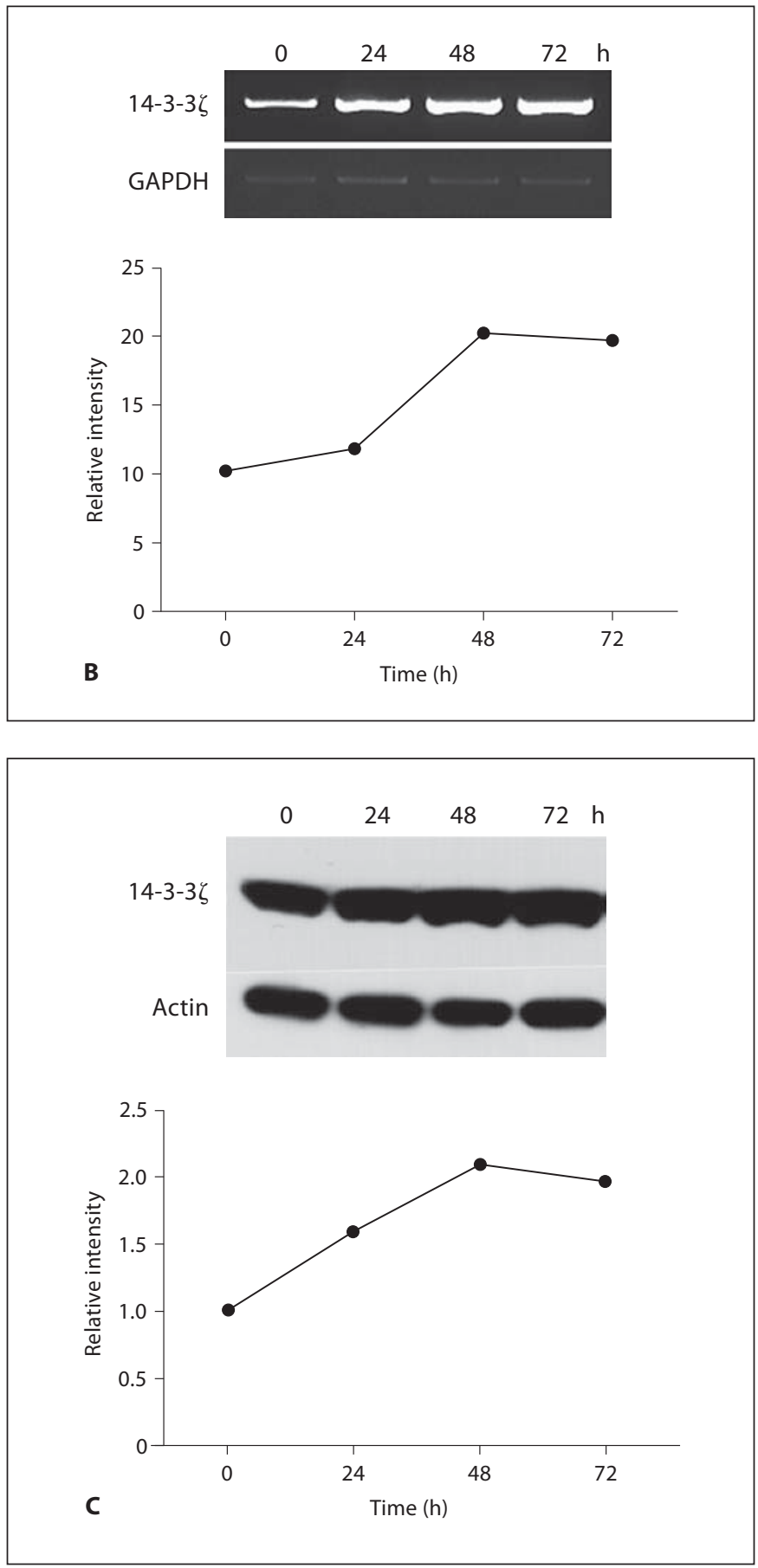

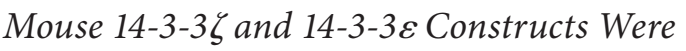

\section{Delivered into the NAc Neurons}

Since myc-tagged 14-3-3 $\zeta$ and 14-3-3 $\varepsilon$ DNA constructs were designed, myc protein expression was used to indicate the magnitude of $14-3-3 \zeta$ and $14-3-3 \varepsilon$ protein expression. We first assessed the latency of maximal ex- 


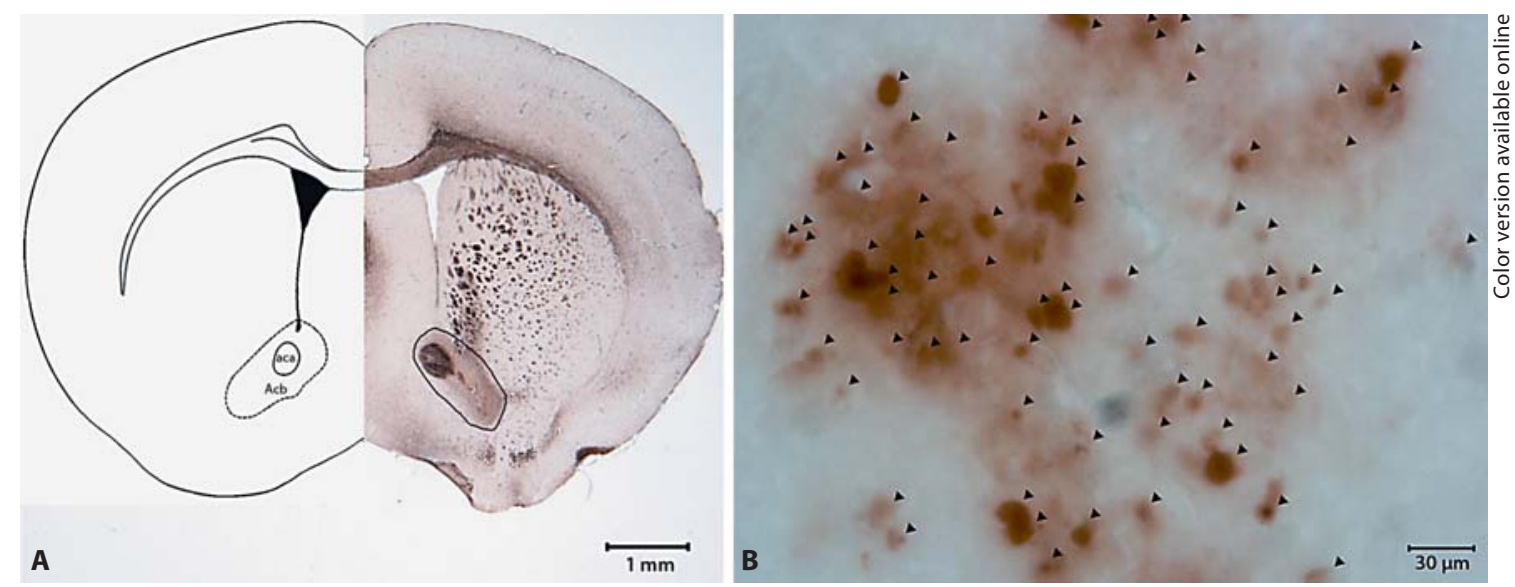

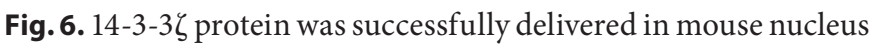
accumbens. A Immunohistochemical methods were used to reveal the infusion site. Mice underwent cardiac perfusion with saline and $4 \%$ paraformaldehyde under sodium pentobarbital anesthesia. Their brains were removed, post-fixed and a $30-\mu \mathrm{m}$ coronal section slice was made within a range of Bregma +2.1 and Bregma +0.5 . The mouse anti-myc antibody (1:500) was incubated with brain slice for $16 \mathrm{~h}$ at $4^{\circ} \mathrm{C}$ and incubated with HRP-conjugated goat anti-mouse antibody (1:1,000; Jackson ImmunoResearch, West Grove, Pa., USA) at room temperature for $1 \mathrm{~h}$, and then visualized using a DAB kit (Vector Laboratories, Burlingame, Calif., USA). 14-3-3 $\zeta$-myc proteins were expressed in the nucleus accumbens. B Triangles represent cells with a myc protein-positive signal (brown color; refers to the online version only) in the nucleus accumbens.

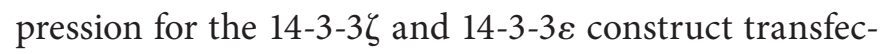
tion in HEK293 cells, human embryonic kidney cells. Myc protein expression was evident starting from $24 \mathrm{~h}$ and peaking at $48 \mathrm{~h}$ after a PEI-mediated $14-3-3 \zeta$ and $14-$ $3-3 \varepsilon$ construct transfection in HEK293 cells (fig. 5A). Then, a total of $1 \mu \mathrm{l}$ PEI and $14-3-3 \zeta / 14-3-3 \varepsilon$ plasmid DNA mixture $(0.5 \mu \mathrm{g}$ plasmid DNA/ $\mu$ l mixture) was infused into each side of mouse NAc with a Hamilton syringe driven by a microdialysis pump (CMA/Microdialysis, Stockholm, Sweden) at a rate of $0.5 \mu \mathrm{l} / \mathrm{min}$. As PEI14-3-3 $\zeta$ plasmid DNA complex was injected into mouse

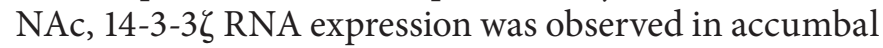
tissue extracts (fig. 5B). 14-3-3 $\zeta$ protein expression was found to peak $48 \mathrm{~h}$ after PEI-mediated transfection in accumbal tissue extracts (fig. 5C). Likewise, $14-3-3 \varepsilon$ protein expression was noted to peak $48 \mathrm{~h}$ after PEI-mediated 14 3-3 $\varepsilon$ plasmid DNA transfection in the NAc (data not

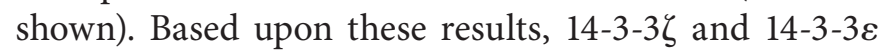
constructs were delivered into NAc neurons 2 days before the cocaine-induced CPP test in the following behavioral experiments. Infusion sites for each animal were validated by immunohistochemical methods (fig. 6A). It was of importance to note that myc proteins were clearly expressed in the NAc (fig. 6B). Moreover, PEI and 14-3-3 $\zeta$ plasmid DNA complex entered a number of specified neurons (NeuN-positive cells) in the NAc (fig. 7).

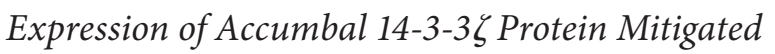

Conditioned Cue/Context-Mediated Cocaine Memory

Retrieval in a Long-Lasting Manner

Two behavioral procedures were used to study the effect of accumbal 14-3-3 $\zeta$ overexpression on cocaine-induced CPP (fig. 8). After the cocaine-induced CPP training, mice underwent three cocaine-free tests (tests 1,2 and 3). Intra-accumbal infusion of $14-3-3 \zeta / 14-3-3 \varepsilon$ plasmid DNA or vector was done 2 days before test 1 in procedure 1 and 2 days before test 2 in procedure 2 (fig. 8). Mice received a 15 -min cocaine priming test 1 day before test 3 in both procedures 1 and 2 . The cocaine-priming test in procedure 1 was used to specifically verify the acquisition of cocaine-induced CPP. All groups of mice exhibited reliable cocaine-induced CPP (procedure 1: $\mathrm{t}_{42}=$

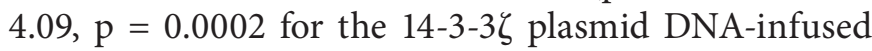
group, $\mathrm{n}=22 ; \mathrm{t}_{38}=11.49, \mathrm{p}<0.0001$ for the vector-infused group, $\mathrm{n}=20$; procedure 2 : $\mathrm{t}_{32}=10.24, \mathrm{p}<0.0001$ for the $14-3-3 \zeta$ plasmid DNA-infused group, $n=17 ; \mathrm{t}_{32}=9.873$, $\mathrm{p}<0.0001$ for the vector-infused group, $\mathrm{n}=17$; fig. 9A, $B)$. In procedure 1, a one-way repeated measure ANOVA revealed that the 14-3-3 $\zeta$ plasmid DNA-infused group had a lower CPP magnitude than that of the vector-infused group in tests 1,2 and $3\left(\mathrm{~F}_{(1,160)}=80.64, \mathrm{p}<0.0001\right.$; fig. 9A). Nonetheless, CPP magnitude was significantly increased in the cocaine-priming test for the 14-3-3 $\zeta$ 

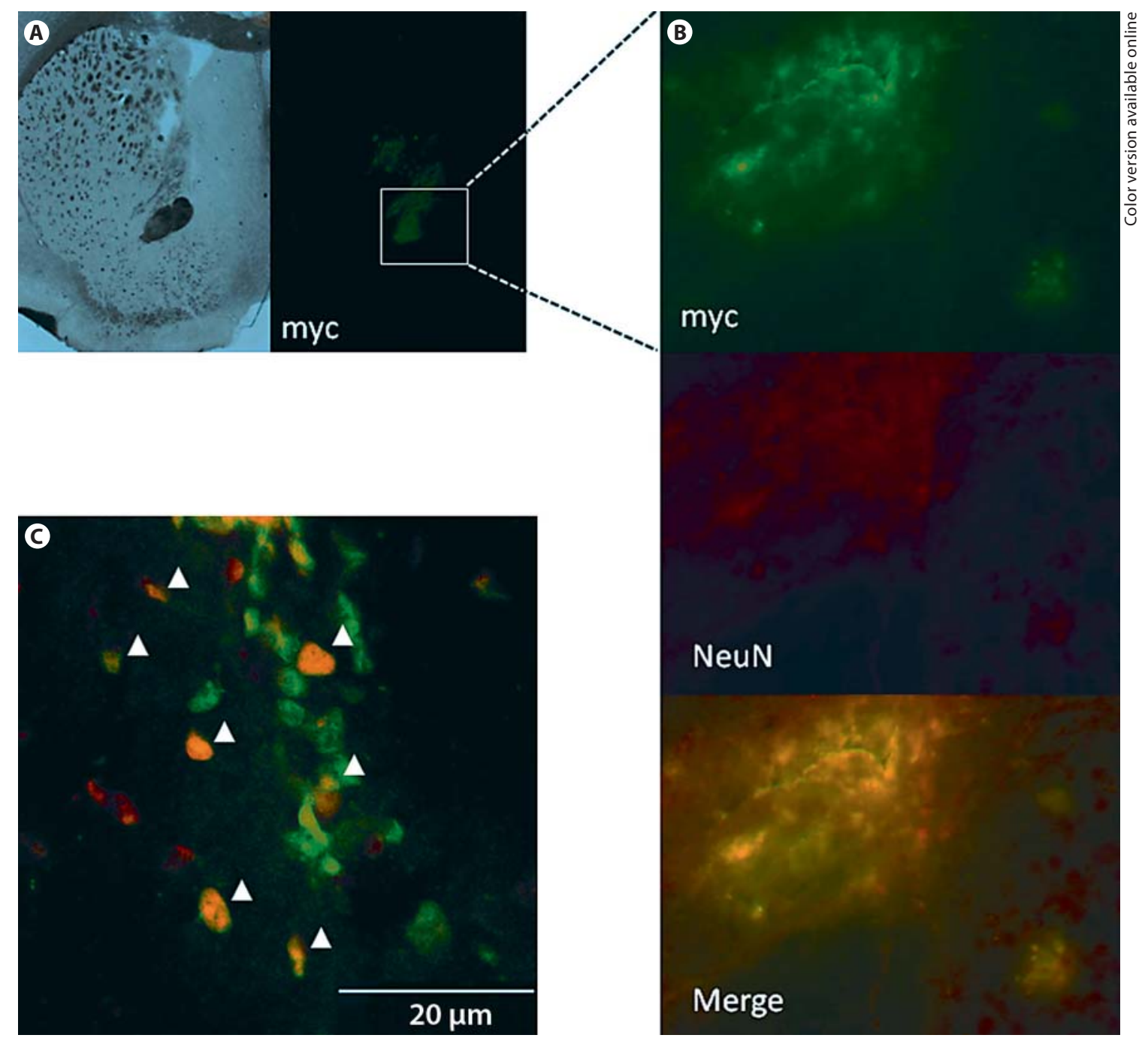

myc

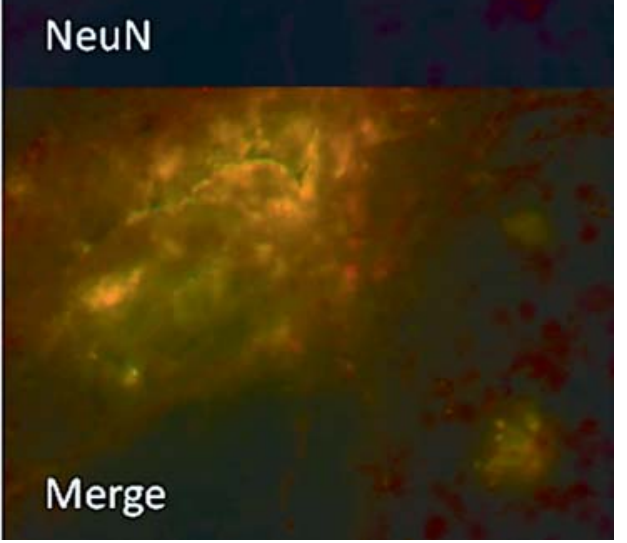

Fig. 7. 14-3-3 $\zeta$ protein was successfully expressed in accumbal neurons. Two days after intra-accumbal pcDNA3.1-14-3-3ל-mycHis plasmid DNA infusion, brain slices were obtained and incubated with rabbit anti-myc tag antibody (1:500; Abcam, Cambridge, UK) and NeuN antibody (1:500; Chemicon International, Temecula, Calif., USA) for double labeling purpose. A Bright field was detected via indirect immunofluorescence with anti-myc-tag antibodies, anti-rabbit secondary antibody (Alexa Flour 488 con- jugated goat anti-rabbit IgG). The pcDNA3.1-14-3-3 $\zeta$-myc-His plasmid DNA was transfected into the accumbal region (green). B Double labeling (yellow) of myc-positive (green) and NeuN-positive (red) staining are shown in the nucleus accumbens. C A confocal laser scanning image demonstrates co-localization of mycexpressed cells and neurons (dictated by triangles). Colors refer to the online version only. plasmid DNA-infused group $\left(\mathrm{F}_{(3,160)}=5.745, \mathrm{p}=0.0009\right.$; fig. 9A). In addition, there was an interactive effect of treatment and test on CPP magnitude $\left(\mathrm{F}_{(3,160)}=4.292\right.$, $\mathrm{p}=0.0061$; fig. $9 \mathrm{~A})$. In procedure 2 , a one-way repeated measure ANOVA revealed that the $14-3-3 \zeta$ plasmid DNAinfused group exhibited lower CPP magnitude as compared to vector-infused group in tests 2 and $3\left(\mathrm{~F}_{(1,128)}=\right.$ 24.91, $\mathrm{p}<0.0001$; fig. 9B). The $14-3-3 \zeta$ plasmid DNA-in- fused group displayed comparable CPP magnitude as did the vector-infused group in the cocaine priming test $\left(\mathrm{F}_{(3,128)}=11.78, \mathrm{p}<0.0001\right.$; fig. 9B). Finally, there was an interactive effect of treatment and test on CPP magnitude $\left(\mathrm{F}_{(3,128)}=5.825, \mathrm{p}=0.0009\right.$; fig. $\left.9 \mathrm{~B}\right)$. Three groups of mice (14-3-3 $\zeta$ plasmid DNA-infused, vector-infused, and naïve control group (with cannula implantation but no infusion), $n=4$ for each group) were used to test whether 
Fig. 8. Two procedures were used for behavioral experiments. Mice were measured for their unconditioned preference in a 15 -min free navigation pretest. Then an 8-day cocaine-induced CPP training procedure was employed. On days 10, 17 and 25 around noon, mice received a 15 min preference test (tests 1,2 and 3) in a cocaine-free status. Intra-accumbal infusion of plasmid DNA or vector was done on day 8 for the procedure 1 , while infusion was on day 15 for procedure 2 . On day 24 around noon, mice received a $15-\mathrm{min}$ cocaine-priming test.

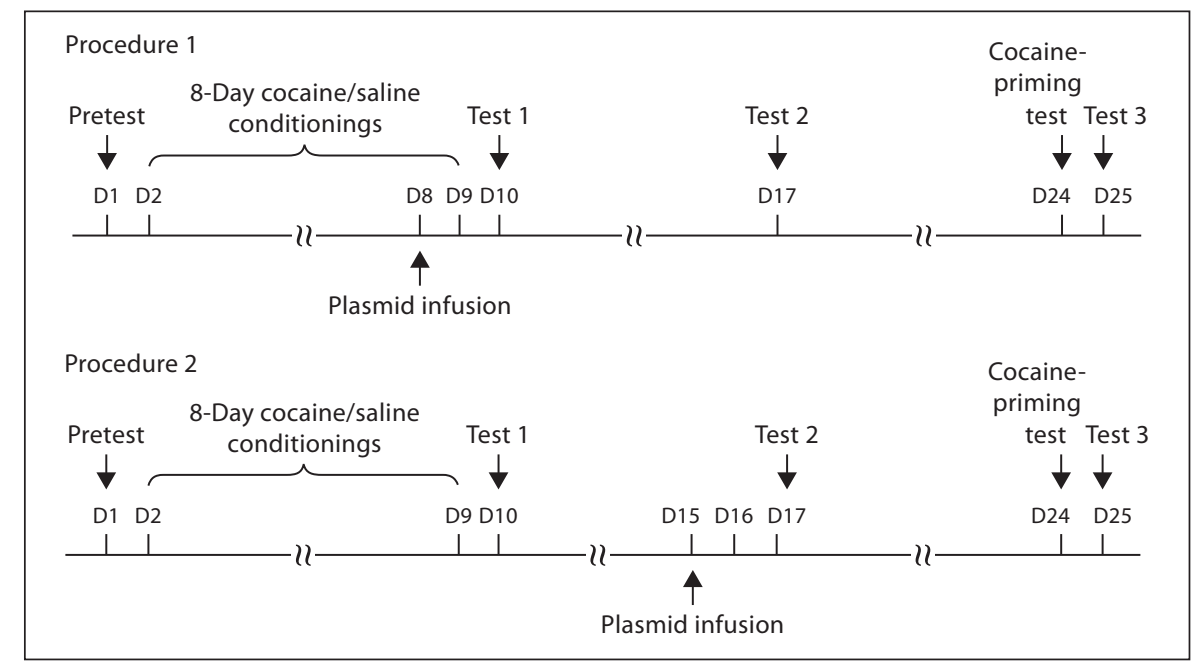

accumbal 14-3-3 $\zeta$ plasmid DNA infusion impaired mouse locomotor activity. It was of importance to note that accumbal 14-3-3 $\zeta$ expression did not affect mouse locomotor activity 2 days after $14-3-3 \zeta$ plasmid DNA infusion $\left(\mathrm{F}_{(2,9)}=0.0034, \mathrm{p}=0.99\right.$ in the pretest; $\mathrm{F}_{(2,9)}=0.1241, \mathrm{p}=$ 0.88 in the posttest; fig. 9C). These results suggest that decreased CPP magnitude in procedure 1 or 2 was not due to the motor activity-impairing effect produced by ac-

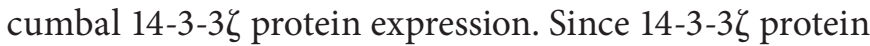
was documented to modulate tyrosine hydroxylase activity and DA synthesis in MN9D cells [28], accumbal DA and its primary metabolite, DOPAC, were assessed for the potential effect of 14-3-3 $\zeta$ plasmid DNA infusion on DA metabolism in mouse NAc. Three groups of mice (14-3-3 $\zeta$ plasmid DNA-infused group, $\mathrm{n}=5$; vector-infused group, $\mathrm{n}=8$; naïve control group, $\mathrm{n}=8$ ) were used. Two days after intra-accumbal infusion, mice were sacrificed and their accumbal tissues were dissected. The results show that accumbal DA and DOPAC contents are similar in 143-3 $\zeta$ plasmid DNA-, vector-infused and naïve control group $\left(\mathrm{F}_{(2,18)}=0.5933, \mathrm{p}=0.5624\right.$ for $\mathrm{DA}$ content level; $\mathrm{F}_{(2,18)}=0.6414, \mathrm{p}=0.537$ for DOPAC content level; fig. 9D).

Accumbal 14-3-3e Protein Did Not Affect Conditioned Cue/Context-Mediated Cocaine Memory Retrieval

In an attempt to further specify the role of accumbal $14-3-3 \zeta$ protein in this cocaine memory, $14-3-3 \varepsilon$ plasmid DNA-infused mice were used to serve as negative controls. All groups of mice exhibited reliable cocaine-induced CPP (procedure 1: $\mathrm{t}_{16}=6.555, \mathrm{p}<0.0001$ for $14-3-3 \varepsilon$ plasmid DNA-infused group, $\mathrm{n}=9 ; \mathrm{t}_{16}=8.117, \mathrm{p}<0.0001$ for the vector-infused group, $\mathrm{n}=9$; procedure $2: \mathrm{t}_{24}=8.98$, $\mathrm{p}<0.0001$ for the $14-3-3 \varepsilon$ plasmid DNA-infused group, $\mathrm{n}=13 ; \mathrm{t}_{22}=10.81, \mathrm{p}<0.0001$ for the vector-treated group, $\mathrm{n}=12$; fig. $9 \mathrm{E}, \mathrm{F}$ ). In procedure 1 , a one-way repeated measure ANOVA revealed that intra-accumbal infusion of 4-3-3e plasmid DNA did not affect CPP magnitude in tests 1,2 and 3 , or cocaine priming test $\left(\mathrm{F}_{(1,64)}=0.3148\right.$, $\mathrm{p}=0.5767$; fig. 9E). Cocaine-induced CPP magnitude remained unaltered across tests in both $4-3-3 \varepsilon$ plasmid DNA- and vector-infused groups $\left(\mathrm{F}_{(3,64)}=0.4153, \mathrm{p}=\right.$ 0.7426 ; fig. 9E). Moreover, there was no treatment and test interaction $\left(\mathrm{F}_{(3,64)}=0.0836, \mathrm{p}=0.9688\right.$; fig. 9E). In procedure 2 , a one-way repeated measure ANOVA revealed that intra-accumbal infusion of 14-3-3 $\varepsilon$ plasmid DNA did not affect CPP magnitude $\left(\mathrm{F}_{(1,92)}=1.97, \mathrm{p}=0.1638\right.$; fig. 9F). Cocaine-induced CPP magnitude was not altered across tests $\left(\mathrm{F}_{(3,92)}=0.0633, \mathrm{p}=0.9792\right.$; fig. 9F). Finally, there was no treatment and test interaction on CPP magnitude $\left(\mathrm{F}_{(3,92)}=0.0597, \mathrm{p}=0.9808\right.$; fig. 9F $)$.

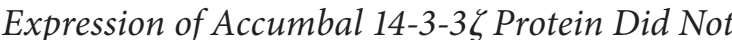 Affect Food-Induced CPP}

Following the training procedure, food-induced CPP was reliably established in 3 groups of mice $\left(t_{8}=7.847\right.$, $\mathrm{p}<0.0001$ for the 14-3-3 $\zeta$ plasmid DNA-infused group, $\mathrm{n}=5 ; \mathrm{t}_{8}=7.837, \mathrm{p}<0.0001$ for the vector-infused group, $\mathrm{n}=5 ; \mathrm{t}_{8}=6.132, \mathrm{p}=0.0003$ for the non-infused group, $\mathrm{n}=5$; fig. 10). Moreover, these 3 groups of mice exhibited comparable food-induced CPP magnitude in test 1 $\left(\mathrm{F}_{(2,14)}=0.3282, \mathrm{p}=0.7265\right)$. Likewise, 3 groups of mice exhibited comparable food-induced CPP magnitude in test 2 approximately $48 \mathrm{~h}$ after the intra-accumbal infu$\operatorname{sion}\left(\mathrm{F}_{(2,14)}=1.56, \mathrm{p}=0.2499\right)$. 


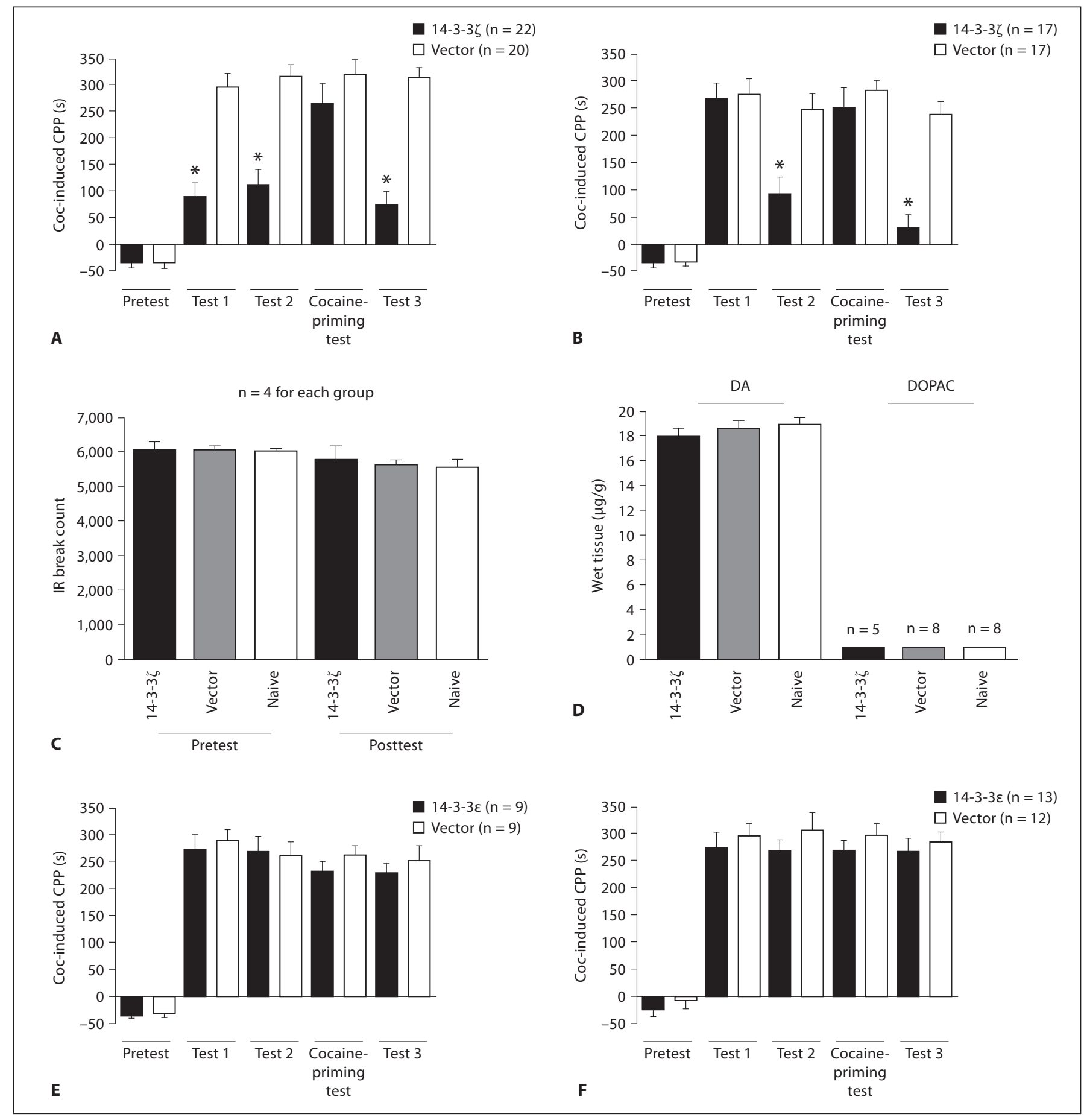

Fig. 9. Over-expression of accumbal 14-3-3 $\zeta$ protein decreased conditioned cue-mediated cocaine memory retrieval. Over-expression of $14-3-3 \zeta$ protein in the nucleus accumbens 2 days before the test 1 in procedure $1(\mathbf{A})$ and 2 days before the test 2 in procedure 2 (B) decreased the following conditioned cue/contextmediated cocaine-induced CPP. However, over-expression of accumbal $14-3-3 \zeta$ protein did not affect cocaine-mediated retrieval of cocaine-induced CPP in either procedure $1(\mathbf{A})$ or procedure 2

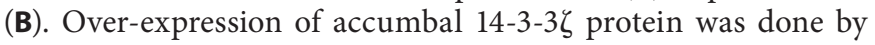

employing procedure 2. Two days following the expression of accumbal 14-3-3 $\zeta$ protein, mouse locomotor activity (C) and local DA metabolism (D) in the nucleus accumbens were not altered, suggesting dissociations of motor-impairing or DA-altering effect

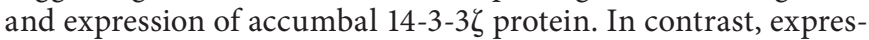
sion of $14-3-3 \varepsilon$ protein in the nucleus accumbens either 2 days before test $1(\mathbf{E})$ or 2 days before test $2(\mathbf{F})$ failed to affect conditioned cue/context- or cocaine-mediated, cocaine-induced CPP retrieval in procedure 1 or procedure $2 .{ }^{*} \mathrm{p}<0.05$. 


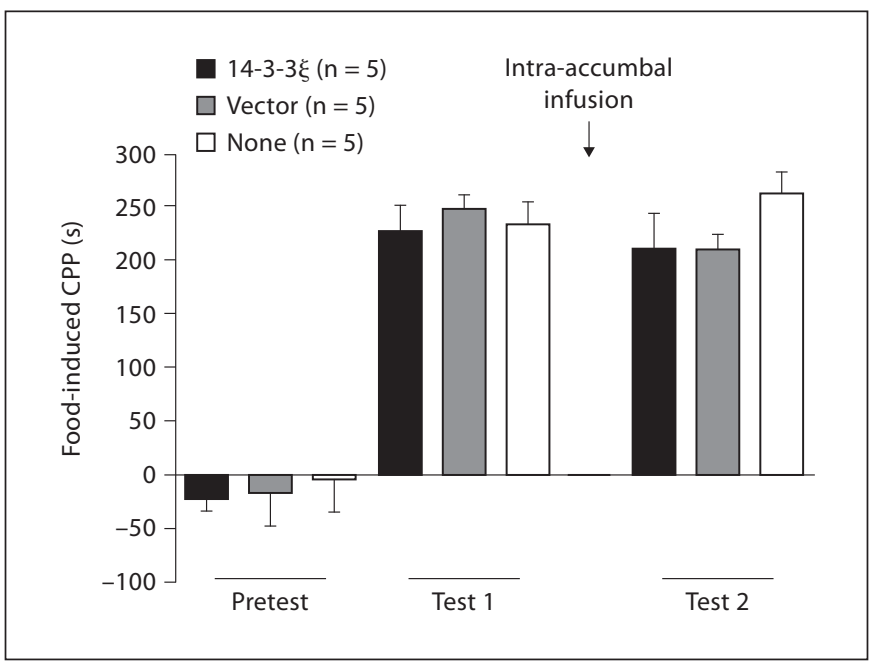

Fig. 10. Over-expression of accumbal 14-3-3 $\zeta$ protein did not affect the retrieval of food-induced CPP. Three groups of mice $(\mathrm{n}=$ 5 for each group) all exhibited reliable food-induced CPP in test 1. Over-expression of $14-3-3 \zeta$ protein in the nucleus accumbens did not alter mouse food-induced CPP performance in test 2 .

\section{Discussion}

In this study, we found that mice exhibiting cocaineinduced CPP displayed downregulated $14-3-3 \zeta$ protein in

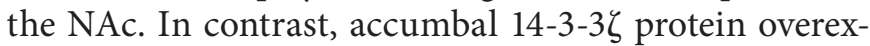
pression significantly decreased mouse CPP magnitude in CPP tests. Overexpression of $14-3-3 \zeta$ protein in the NAc appeared to be negatively associated with the expression of the cocaine-induced CPP. Nonetheless, 14-3$3 \zeta$ protein overexpression in the NAc did not decrease $\mathrm{CPP}$ magnitude in the cocaine priming test, suggesting a minor role of accumbal 14-3-3 $\zeta$ protein overexpression in modulating the storage of such a cocaine-conditioned memory. Although 14-3-3 $\zeta$ plasmid DNA-infused mice exhibited low cocaine-induced CPP magnitude in test 1 of procedure 1, their cocaine-induced CPP magnitude in a later cocaine-priming test was comparable with that of the vector-infused mice. Therefore, overexpression of 143-3 $\zeta$ protein in the NAc did not seem to affect the formation of cocaine-induced CPP. Therefore, we suggest that downregulated accumbal 14-3-3 $\zeta$ protein could be responsible for successful retrieval of cocaine-induced CPP. Most importantly, reversal of $14-3-3 \zeta$ protein downregulation in the NAc was found to effectively decrease conditioned cue/context-mediated cocaine memory retrieval. The latter finding indicated that accumbal 14-3-3 $\zeta$ protein was a potential target for treating cocaine-condi- tioned memory and thus memory-induced craving for cocaine.

Although overexpression of accumbal 14-3-3 $\zeta$ protein did not decrease cocaine-primed CPP retrieval, this treatment was effective in mitigating conditioned cue-mediated CPP retrieval after the cocaine-priming test. Moreover, overexpression of accumbal $14-3-3 \zeta$ protein before the CPP tests reliably decreased subsequent conditioned cue-mediated CPP retrieval across a 1 - to 2 -week period. The implication of these results was that overexpression of $14-3-3 \zeta$ protein in the NAc might decrease conditioned cue/context-mediated CPP retrieval for a period of time. Since addicts are vulnerable to drug memory-induced craving over an extended period of time after abstinence [1-3], it is worthwhile to develop a long-term treatment protocol against the drug-conditioned memory retrieval. Our results suggest that overexpression of 14-3-3 $\zeta$ protein in accumbal neurons exerted a long-lasting inhibitory effect on the retrieval of cocaine-conditioned memory. Therefore, using 14-3-3 $\zeta$ protein as a treatment target seemed to be a promising strategy in cocaine dependence therapy.

As a nonspecific effect associated with accumbal 14-3$3 \zeta$ protein overexpression was assessed, we observed that accumbal 14-3-3 $\zeta$ protein overexpression did not affect mouse locomotor activity 2 days after intra-accumbal infusion. This finding ruled out the possibility that accumbal 14-3-3 $\zeta$ overexpression decreased cocaine-induced CPP magnitude by impairing mouse locomotor activity. Moreover, accumbal DA and DOPAC levels remained unaltered 2 days after the $14-3-3 \zeta$ plasmid DNA or vector infusions, suggesting that PEI and $14-3-3 \zeta$ plasmid DNA mixture or intra-accumbal infusion itself did not cause dopaminergic terminal deficits. A previous study documented that $14-3-3 \zeta$ protein decreased tyrosine hydroxylase activity and subsequent DA synthesis in MN9D cells [30]. However, we here report that expression of accumbal $14-3-3 \zeta$ protein did not affect DA and its primary metabolite, DOPAC, in the NAc. The discrepancy could arise from differences in cell types and 14-3-3 $\zeta$ expression magnitude. First, we demonstrated that a number of accumbal neurons were transfected with $14-3-3 \zeta$ constructs. However, most of these accumbal neurons are characterized as GABAergic neurons [31]. Therefore, intra-accumbal infusion with $14-3-3 \zeta$ constructs is not expected to decrease accumbal DA or DOPAC level in GABAergic neurons. Second, in this study we overexpressed $14-3-3 \zeta$ protein in an attempt to reverse CPP-decreased 14-3-3 $\zeta$ protein. However, reversal of cocaine-induced CPP-decreased 14-3-3 $\zeta$ protein could be different 
from overexpression of $14-3-3 \zeta$ protein in another study [30]. Finally, 14-3-3- $\zeta$ overexpression in the NAc is less likely to produce a long-term impairing effect on accumbal function. So far many lines of evidence have implicated the NAc in the extinction and maintenance of cocaine-supported behavior [32]. If a long-term functional impairment is associated with intra-accumbal 14-3-3 $\zeta$ overexpression, it is reasonable to predict that accumbens-supported behavior should be affected. However, we found that such treatment did not affect CPP performance in a cocaine-priming condition or food-induced $\mathrm{CPP}$ performance.

In theory, cocaine-induced CPP can be retrieved by two means. Both presentation of an unconditioned stimulus (receiving a cocaine injection) and presentation of a conditioned stimulus (cocaine-conditioned cue/context) may provide the memory retrieval cues [33]. Although such a cocaine-conditioned memory is expected to be formed following a classical conditioning procedure, these two memory retrieval cues may be routed through different neural pathways and synapses. To date, inconsistent results between conditioned cue/context-induced and cocaine-induced memory retrieval are frequently explained by intact cocaine-conditioned memory storage but memory retrieval failure. However, another interpretation of these inconsistent results is that there are two independent sets of synapses formed following the cocaine-induced CPP training. Each set of synaptic changes is responsible for modulating unconditioned stimulus(cocaine) and conditioned stimulus- (cocaine-conditioned cue/context) induced memory retrieval (an approaching response for the cocaine-paired compartment in cocaine induced $\mathrm{CPP}$ ). Using similar training protocols, for example, methamphetamine $(1 \mathrm{mg} / \mathrm{kg} /$ conditioning) and cocaine (5 $\mathrm{mg} / \mathrm{kg} /$ conditioning) produce similar CPP magnitudes in a drug-free test [34]. However, we report that single methamphetamine prim- ing injection impairs the retrieval of methamphetamineinduced CPP, while a cocaine-priming injection does not affect, if not enhance, cocaine-induced CPP retrieval [34]. Therefore, it is reasonable to suspect that cocaine induces CPP retrieval via certain synaptic changes different from those induced by presentation of conditioned cue/context.

14-3-3 protein has been thought to function as homoor heterodimers that bind with varieties of proteins. A previous report indicates that 14-3-3 protein may interact with varieties of proteins and subsequently affect the degradation of these proteins [35]. Lately, 14-3-3 protein is found to bind to Nedd4-2 protein and the formed complexes can modulate the ubiquitination of the epithelial sodium channel [36]. Protein ubiquitination is a critical step for $26 \mathrm{~S}$ proteasome-mediated protein degradation. In fact, polyubiquitination and protein degradation in postsynaptic neurons are necessary to modulate the extinction of a retrieved fear memory [37]. Therefore, 14-3$3 \zeta$ overexpression in the NAc is suspected to mitigate conditioned cue/context-mediated cocaine-induced CPP retrieval by facilitating formation of ubiquitinated proteins and/or proteasome-mediated protein degradation in the NAc. Here we provide a scenario to explain our primary finding that accumbal $14-3-3 \zeta$ protein overexpression mitigated the retrieval of conditioned cue/context-mediated cocaine-induced CPP. We hypothesize that 14-3-3 $\zeta$-enhanced protein degradation in the NAc could be responsible for the quick extinction of the conditioned cue/context-mediated cocaine memory in this study.

\section{Acknowledgements}

This research is supported by ROC National Science Council grants 97-2321-B-006-010, 97-2410-H-006-074-MY3 and 982410-H-006-019 to L.Y.

\section{References}

1 Dackis CA, O’Brien CP: Cocaine dependence: a disease of the brain's reward centers. J Subst Abuse Treat 2001;21:111-117.

- 2 O'Brien CP, Childress AR, McLLellan AT, Ehrman R: Classical conditioning in drugdependent humans. Ann NY Acad Sci 1992; 654:400-415.

-3 O'Brien CP, Childress AR, Ehrman R, Robbins SJ: Conditioning factors in drug abuse: can they explain compulsion? J Psychopharm 1998;12:15-22.

Accumbal 14-3-3 $\zeta$ Protein Downregulation Cocaine-Conditioned Memory
4 Ehrman RN, Robbins SJ, Cornish JW, Childress AR, O'Brien CP: Failure of ritanserin to block cocaine cue reactivity in humans. Drug Alcohol Depend 1996;42:167-174.

5 Bossert JM, Busch RF, Gray SM: The novel mGluR2/3 agonist LY379268 attenuates cueinduced reinforcement of heroin seeking. Neuroreport 2005;16:1013-1016.

6 Feltenstein MW, See RE: Potentiation of cueinduced reinstatement of cocaine-seeking in rats by the anxiogenic drug yohimbine. Behav Brain Res 2006;174:1-8.
7 Lee JL, Milton AL, Everitt BJ: Cue-induced cocaine seeking and relapse are reduced by disruption of drug memory reconsolidation. J Neurosci 2006;26:5881-5887.

8 Zhao, Dayas CV, Aujla H, Baptista MA, Martin-Fardon R, Weiss F: Activation of group II metabotropic glutamate receptors attenuates both stress and cue-induced ethanol-seeking and modulates c-fos expression in the hippocampus and amygdale. J Neurosci 2006 ; 26:9967-9974. 
$>9$ Moffett MC, Goeders NE: CP-154,526, a CRF type 1 receptor antagonist, attenuates the cue- and methamphetamine-induced reinstatement of extinguished methamphetamine-seeking behavior in rats. Psychopharmacolgy (Berl) 2007;190:171-180.

$\checkmark 10$ Rogers JL, See RE: Selective inactivation of the ventral hippocampus attenuates cue-induced and cocaine-primed reinstatement of drug-seeking in rats. Neurobiol Learn Mem 2007;87:688-692.

- 11 Yan Y, Yamada K, Nitta A, Nabeshima T: Transient drug-primed but persistent cueinduced reinstatement of extinguished methamphetamine-seeking behavior in mice. Behav Brain Res 2007;177:261-268.

$\checkmark 12$ Dravolina OA, Zakharova ES, Shekunova EV, Zvartau EE, Danysz W, Bespalov AY: MGlu1 receptor blockade attenuates cueand nicotine-induced reinstatement of extinguished nicotine self-administration behavior in rats. Neuropharmacology 2007;52: 263-269.

>13 Kuo YM, Liang KC, Chen H-H, Cherng CG, Lee H-T, Lin Y, Huang A-M, Liao R-M, Yu L: Cocaine- but not methamphetamine-associated memory requires de novo protein synthesis. Neurobiol Learn Mem 2007;87:93100.

14 Lai Y-T, Fan H-Y, Cherng CG, Chiang C-Y, Kao G-S, Yu L: Activation of amygdaloid PKC pathway is necessary for conditioned cues-provoked cocaine memory performance. Neurobiol Learn Mem 2008;90:164170.

- 15 Fan H-Y, Cherng GC, Yang F-Y, Cheng L-Y, Tsai C-J, Lin L-C, Yu L: Systemic treatment with protein synthesis inhibitors attenuates the expression of cocaine memory. Behav Brain Res 2010;208:522-527.

>16 Mameli M, Halbout B, Creton C, Engblom D, Parkitna JR, Spanagel R, Luscher C: Cocaine-evoked synaptic plasticity: persistence in the VTA triggers adaptations in the NAc. Nat Neurosci 2009;12:1036-1041.
17 Huang YH, Lin Y, Mu P, Lee BR, Brown TE, Wayman G, Marie H, Liu W, Yan Z, Sorg BA, Schuter OM, Zukin RS, Dong Y: In vivo cocaine experience generates silent synapses. Neuron 2009;63:40-47.

18 Miller CA, Marshall JF: Molecular substrates for retrieval and reconsolidation of cocaineassociated contextual memory. Neuron 2005;47:873-884.

19 Malvaez M, Sanchis-Segura C, Vo D, Lattal KM, Wood MA: Modulation of chromatin modification facilitates extinction of cocaine-induced conditioned place preference. Biol Psychiatry 2009;67:36-43.

20 Calu DJ, Schoenbaum G: Cocaine-paired cues activate aversive representations in accumbens neurons. Neuron 2008;13:633.

21 Carelli RM, Ijames SG: Nucleus accumbens cell firing during maintenance, extinction, and reinstatement of cocaine self-administration behavior in rats. Brain Res 2000;866: 44-54.

22 Childress AR, Mozley PD, McElgin W, Fitzgerald J, Reivich M, O’Brien CP: Limbic activation during cue-induced cocaine craving. Am J Psychiatr 1999;156:11-18.

23 Grant S, London ED, Newlin DB, Villemagne VL, Liu X, Contoreqqi C, Phillips RL, Kimes AS, Marqolin A: Activation of memory circuits during cue-elicited cocaine craving. Proc Natl Acad Sci USA 1996;93:1204012045.

24 Liao P-C, Kuo Y-M, Hsu H-C, Cherng CG, $\mathrm{Yu}$ L: Local proteins associated with methamphetamine-induced nigrostriatal dopaminergic neurotoxicity. J Neurochem 2005; 95:160-168.

25 Abdallah B, Hassan A, Benoist C, Goula D, Behr JP, Demeneix AB: A powerful nonviral vector for in vivo gene transfer into the adult mammalian brain: polyethylenimine. $\mathrm{Hu}$ man Gene Ther 1996;7:1947-1954.

26 Boussif O, Lezoualch F, Zanta MA, Mergny MD, Scherman D, Demeneix B, Behr JP: A versatile vector for gene and oligonucleotide transfer into cells in culture and in vivo: polyethylenimine. Proc Natl Acad Sci USA 1995;92:7297-7301.

-27 Kircheis R, Wightman L, Wagner E: Design and gene delivery activity of modified polyethylenimines. Adv Drug Deliv Rev 2001;53: 341-358.
28 Ho M-C, Cherng CG, Tsai Y-PN, Chiang C-Y, Chuang J-Y, Kao S-F, Yu L: Chronic treatment with monoamine oxidase- $\mathrm{B}$ inhibitors decreases cocaine reward in mice. Psychopharmacology (Berl) 2009;205:141149.

29 Ke J-J, Chen H-I, Jen CJ, Kuo Y-M, Cherng CG, Tsai Y-P N, Ho M-C, Tsai C-W, Yu L: Mutual enhancement of central neurotoxicity induced by ketamine followed by methamphetamine. Toxic Appl Pharmacol 2007; 227:239-247.

-30 Wang J, Lou H, Pedersen CJ, Smith AD, Perez RG: $14-3-3 \zeta$ contributes to tyrosine hydroxylase activity in MN9D cells: localization of dopamine regulatory proteins to mitochondria. J Biol Chem 2009;284:1401114019.

31 Stratford TR, Kelley AE: GABA in the nucleus accumbens shell participates in the central regulation of feeding behavior. J Neurosci 1997;17:4434-4440.

32 Millan EZ, Narchant NJ, McNally GP: Extinction of drug seeking. Behav Brain Res 2011;217:454-462.

33 Cherng CG, Yu L: Disruption of conditioned drug memories. Chin J Physiol 2010;52:264272 .

34 Cherng CG, Tsai C-W, Tsai Y-P, Ho M-C, Kao S-F, Yu L: Methamphetamine-disrupted sensory processing mediates conditioned place preference performance. Behav Brain Res 2007; 182:103-108.

35 Li X, Song S, Liu Y, Ko SH, Kao HY: Phosphorylation of the histone deacetylase 7 modulates its stability and association with 14-3-3 proteins. J Biol Chem 2004;279: 34201-34208.

36 Snyder PM: Down-regulating destruction: phosphorylation regulates the E3 ubiquitin ligase Nedd4-2. Sci Signal 2009;2:pe41.

37 Lee SH, Choi JH, Lee N, Lee HR, Kim JI, Yu NK, Choi SL, Lee SH, Kiim H, Kaang BK: Synaptic protein degredation underlies destablization of retrieved fear memory. Science 2008;319:1253-1256 